\title{
Longidoridae and nepoviruses in Bulgaria and Slovenia
}

\author{
V. K. PENEVA ${ }^{1}$, G. UREK ${ }^{2}$, S. LAZAROVA ${ }^{1}$, S. ŠIRCA ${ }^{2}$, M. KNAPIČ ${ }^{2}$, M. ELSHISHKA ${ }^{1}$, D. J. F. BROWN ${ }^{1}$
}

\author{
${ }^{1}$ Institute of Biodiversity and Ecosystem Research, Bulgarian Academy of Sciences, 2, Gagarin Street, 1113 Sofia, \\ Bulgaria, E-mail: sasa.sirca@kis.si; ${ }^{2}$ Agricultural institute of Slovenia, Hacquetova ulica 17, 1000 Ljubljana, Slovenia
}

\begin{abstract}
Summary
Data on the distribution of Longidoridae and nepoviruses in Bulgaria and Slovenia are summarized. Six species of Longidorus (L. apulus, L. attenuatus, L. arthensis, L. fasciatus, L. elongatus, L. macrosoma), one Paralongidorus species ( $P$. maximus) and three Xiphinema species $(X$. diversicaudatum, $X$. index, $X$. rivesi) are known as natural vectors of nine nepoviruses in Europe. Currently, 10 and 13 species of Xiphinema; 6 and 15 of Longidorus are reported to occur in Slovenia and Bulgaria, respectively. Paralongidorus maximus has been reported only in Bulgaria. Among the virus vector species $X$. index, $X$. diversicaudatum and L. elongatus occur in both countries, $X$. rivesi only in Slovenia and L. attenuatus, L. macrosoma, $X$. italiae and $P$. maximus only in Bulgaria. A report of $X$. index and Grapevine fanleaf virus (GFLV) in Bulgaria was related to transgenic grape tolerance to the same virus. Nepoviruses have been reported from Slovenia, but despite an evident relationship in the occurrence of GFLV and $X$. index in several vineyards the only laboratory proven transmission is that of TRSV and ToRSV to bait plants by a Slovenian population of $X$. rivesi.
\end{abstract}

Keywords: distribution; longidorids; Longidorus; nepoviruses; Xiphinema

\section{Introduction}

The discovery of the transmission of grapevine fanleaf nepovirus (GFLV) by Xiphinema index Thorne \& Allen, 1950 in vineyards in California (Hewitt et al., 1958) and subsequent studies in Europe (Harrison, 1961, 1964; Cadman, 1963) stimulated research on virus vector nematodes and their associated viruses and interactions in different crops (Taylor \& Brown, 1997; MacFarlane et al., 2002). Much progress has been achieved in elucidating the systematics, taxonomy, phylogeny, ecology and distribution of the family Longidoridae (Alphey \& Taylor, 1986; Hunt,
1993; Coomans et al., 2001; Ye et al., 2004; He et al., 2005) and methods for identifying species, including those of economic importance, have been developed (Abrantes \& Santos, 1997; Arias \& Bravo, 1997; Brown \& Halbrendt, 1997; Ye \& Robbins, 2004; De Luca et al., 2004; Hübschen et al., 2004). However, the taxonomic status of most species belonging to the Xiphinema americanum group, which are the principal nematode vector species in North America, remains controversial, with many species showing rather uniform morphology and separated only by minor differences (Lamberti et al., 2000). Sampling and extraction methods for virus vector nematodes are reviewed by Brown and Boag (1997) and Ploeg and Brown (1997). A considerable amount of effort has been focused on the transmission process resulting in the development of methods and criteria for assessing the virus transmission of plant viruses by longidorid nematodes (Trudgill et al., 1983) and better understanding of the discrete processes and mechanisms involved in the successful transmission and virus and vector specificity (Brown \& Weischer, 1998; MacFarlane et al., 2002).

Particular effort has been devoted to developing techniques enabling detection and identification of nepoviruses both in nematodes and in plants, including sap transmission tests, electron and confocal microscopy, and molecular techniques (Duarte \& Brown, 1997; Wang \& Gerderich, 1998; Digiaro et al., 2007).

Currently, eight Longidorus, one Paralongidorus and nine Xiphinema species have been proven as natural vectors of 12 of the 38 putative members of the genus Nepovirus (MacFarlane et al., 2002).

These viruses threaten crop production by reducing yield, affecting quality, delaying ripening, changing aromatic profiles, and limiting the economic life-span of affected agricultural and horticultural sites. The purpose of this study is to provide a review of the distribution of longidorid nematodes in Bulgaria and Slovenia based on literature sources and new samplings. 


\section{Materials and methods}

Soil samples were collected about the roots of host plants from different locations in Slovenia and Bulgaria. Sampling was carried out with an auger at $10-30 \mathrm{~cm}$ depth. Approximately $500 \mathrm{~cm}^{3}$ of a collected soil sample was gently mixed and divided to $200 \mathrm{~cm}^{3}$ sub-samples. Nematodes were extracted from the soil using a decanting method (Hooper, 1986) followed by the Baermann funnel technique. Extracted longidorid nematodes were picked by hand and fixed in TAF or 4\% formalin solution for morphometrical identification of the species.

The geographical data of locations were collected from the literature and with GPS device in case of findings after
1999. The nematodes distributions maps were created using ArcGIS 9.3 (ESRI, Redlands, USA) software.

\section{Results and discussion}

At present, six species of Longidorus: L. apulus Roca and Bleve-Zacheo, 1977, L. arthensis Brown, Grunder, Hooper, Klinger and Kunz, 1994, L. attenuatus Hooper, 1961, L. elongatus (De Man, 1876) Thorne and Swanger, 1936, L. fasciatus Roca and Lamberti, 1981, L. macrosoma Hooper, 1961, one of Paralongidorus: P. maximus (Bütschli, 1874) Siddiqi, 1964) and three species of Xiphinema: $X$. diversicaudatum (Micoletzky, 1927) Thorne, 1939, $X$. index Thorne and Allen, 1950, $X$. rives $i$

Table 1. Longidorid species and their associated viruses reported to occur in Bulgaria (BG) and Slovenia (SLO)

\begin{tabular}{|c|c|c|c|c|c|}
\hline Species & BG & SLO & Viruses & BG & SLO \\
\hline Longidorus aetnaeus & + & & & & \\
\hline \multirow[t]{2}{*}{ Longidorus attenuatus } & + & & Raspberry ringspot (RpRSV) & + & \\
\hline & & & Tomato black ring (TBRV) & + & \\
\hline Longidorus distinctus & + & & & & \\
\hline Longidorus caespiticola & $+^{2}$ & + & & & \\
\hline Longidorus closelongatus & + & & & & \\
\hline \multirow[t]{2}{*}{ Longidorus elongatus } & + & + & Raspberry ringspot (RpRSV) & + & \\
\hline & & & Tomato black ring (TBRV) & + & \\
\hline Longidorus euonymus & + & & & & \\
\hline Longidorus fagi & + & & & & \\
\hline Longidorus fasciatus & & & Artichoke Italian latent (AILV) & + & \\
\hline Longidorus helveticus & & + & & & \\
\hline Longidorus intermedius & + & & & & \\
\hline Longidorus leptocephalus & + & + & & & \\
\hline Longidorus juvenilis & & + & Raspberry bushy dwarf virus (RBDV) ${ }^{1}$ & & + \\
\hline Longidorus macrosoma & + & & Raspberry ringspot (RpRSV) & + & \\
\hline Longidorus moesicus & + & + & & & \\
\hline Longidorus pisi & + & & & & \\
\hline Longidorus profundorum & + & & & & \\
\hline Longidorus vineacola & + & & & & \\
\hline Paralongidorus maximus & + & & Raspberry ringspot (RpRSV) & & \\
\hline Xiphinema basilgoodeyi & & $+^{2}$ & & & \\
\hline \multirow[t]{2}{*}{ Xiphinema diversicaudatum } & + & + & Arabis mosaic (ArMV) & + & + \\
\hline & & & Strawberry latent ringspot (SLRSV) & + & \\
\hline Xiphinema globosum & & + & & & \\
\hline Xiphinema italiae & + & & Grapevine fanleaf (GFLV) & + & \\
\hline Xiphinema index & + & + & Grapevine fanleaf (GFLV) & + & + \\
\hline Xiphinema ingens & $+^{2}$ & & & & \\
\hline Xiphinema neovuittenezi & + & & & & \\
\hline Xiphinema pirinense & + & & & & \\
\hline Xiphinema rotundatum & & $+^{2}$ & & & \\
\hline Xiphinema turcicum & $+^{2}$ & & & & \\
\hline Xiphinema vuittenezi & + & + & & & \\
\hline Xiphinema americanum sl & & + & & & \\
\hline Xiphinema brevicollum & & + & & & \\
\hline Xiphinema incertum & + & & & & \\
\hline \multirow[t]{2}{*}{ Xiphinema rivesi } & & + & Tobacco ringspot (TRSV) & + & \\
\hline & & & Tomato ringspot (ToRSV) & + & \\
\hline Xiphinema simile & + & & & & \\
\hline Xiphinema pachtaicum & + & + & & & \\
\hline Xiphinema parasimile & + & & & & \\
\hline Xiphinema taylori & + & & & & \\
\hline Vector unknown & & & Grapevine Bulgarian latent virus (GBLV) & + & \\
\hline
\end{tabular}




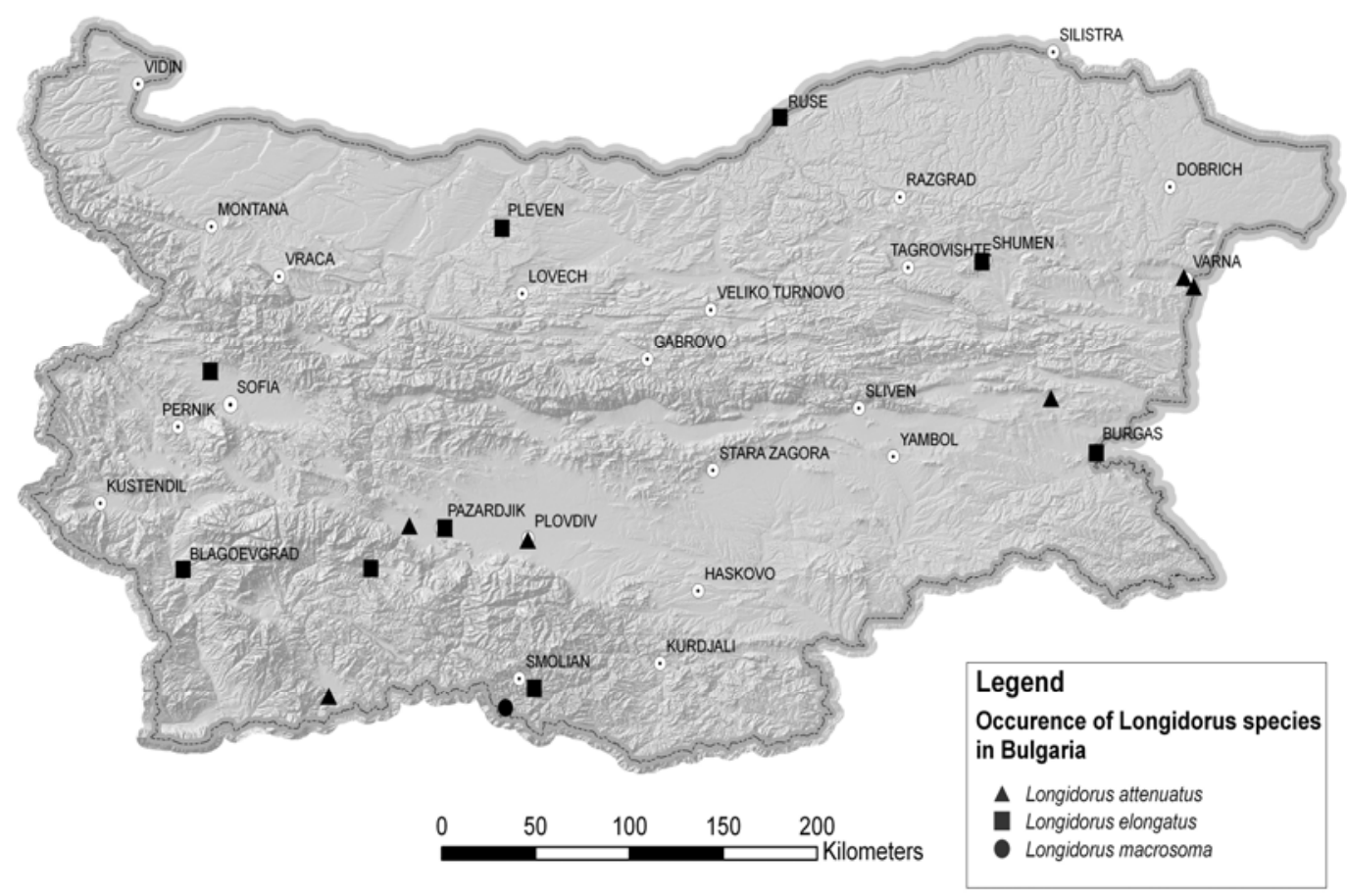

Fig. 1. Distribution of virus vector nematode species of the genus Longidorus in Bulgaria

Dalmasso, 1969, are known as natural vectors of nine nepoviruses in Europe (MacFarlane et al., 2002; Širca et al., 2007b,; Mavrič Pleško et al., 2009) also X. italiae Meyl, 1953, which has been reputed to transmit GFLV in Israel (Cohn et al., 1970), occurs in Europe. In a series of experiments (Catalano et al., 1992), this virus was not detected in, nor transmitted by $X$. italiae populations originating from vineyards in southern Italy. Recently,
GFLV was detected in $X$. italiae specimens from a vineyard in south-western Bulgaria (Širca et al., 2010).

Currently, 10 and 13 species of Xiphinema; 6 and 15 of Longidorus are reported to occur in Slovenia (Urek et al., 2003a, b; Urek \& Širca, 2005; Širca \& Urek, 2004; Širca et al., 2007a, b; Širca \& Urek, 2009) and Bulgaria (Lamberti et al., 1983; Peneva et al., 2005; Lazarova et al., 2008; Mincheva et al., 2008), respectively (Table 1). However,

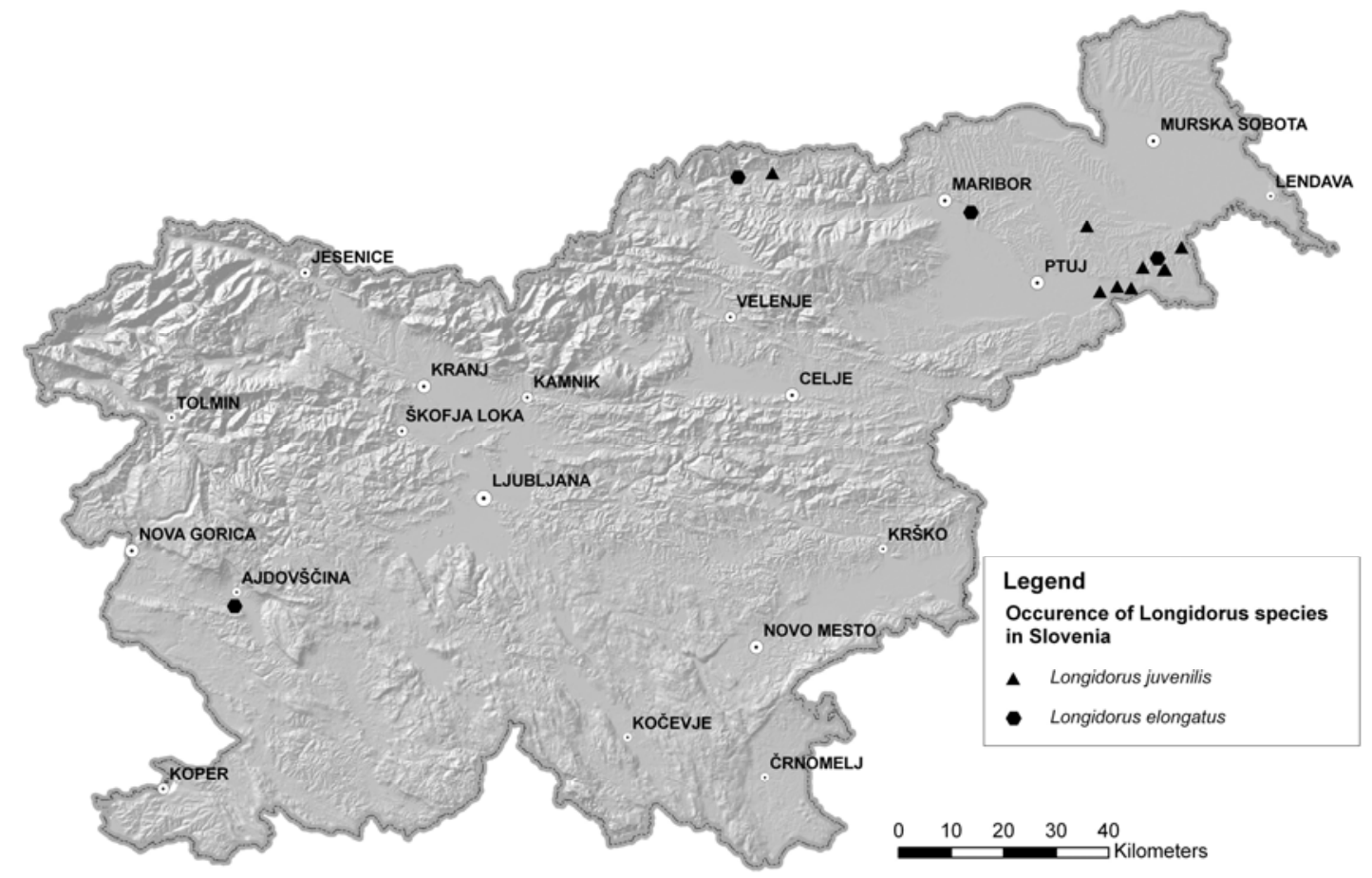

Fig. 2. Distribution of virus vector nematode species of the genus Longidorus in Slovenia 


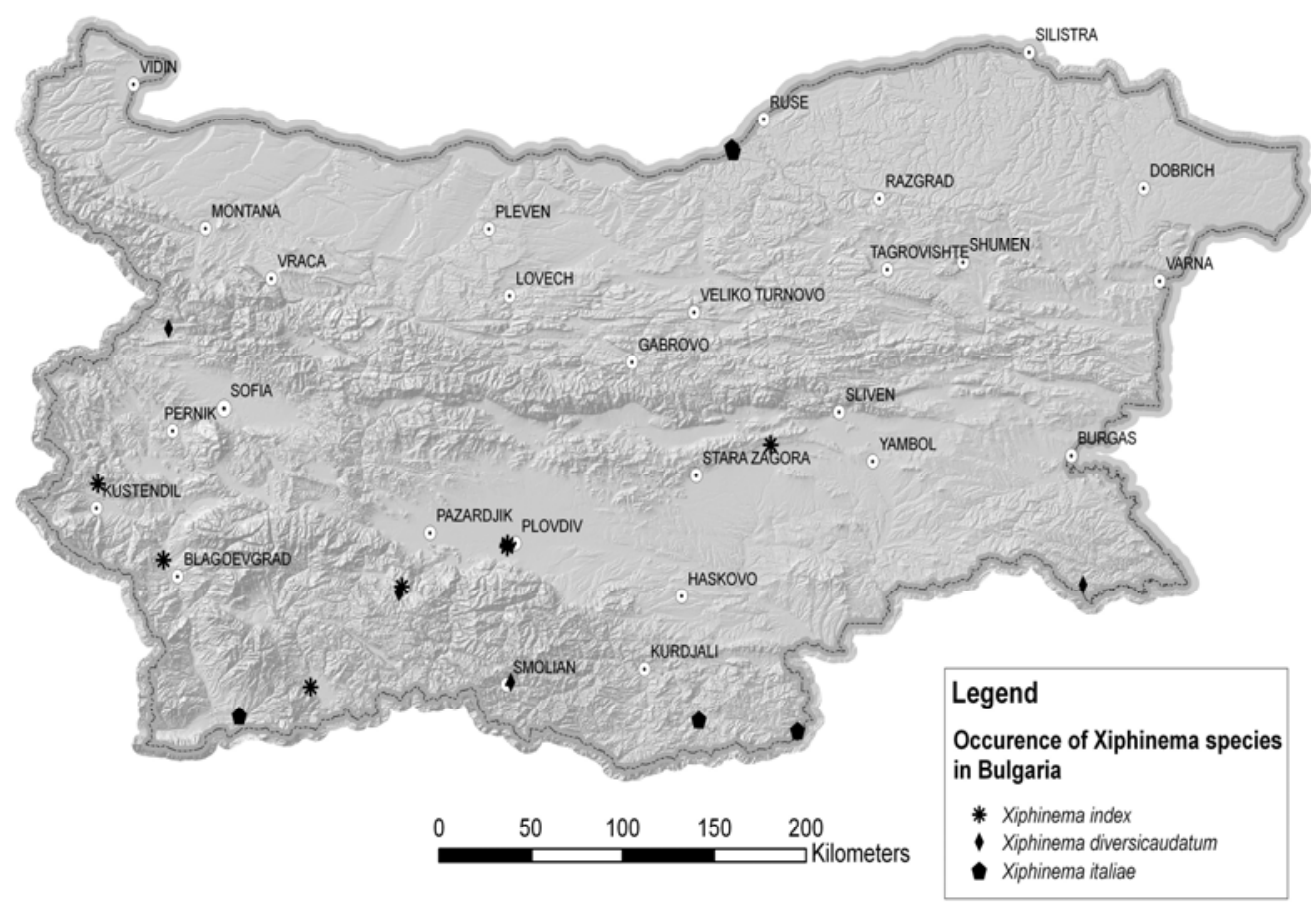

Fig. 3. Distribution of virus vector nematode species of the genus Xiphinema in Bulgaria

some of these records require confirmation e.g. L. caespiticola, $X$. ingens and $X$. turcicum for Bulgaria and $X$. basilgoodeyi, $X$. elongatum and $X$. rotundatum for Slovenia. Among the virus vector species, $X$. index, $X$. diversicaudatum and L. elongatus occurred in both countries, $X$. rivesi was found only in Slovenia and $X$. italiae, L. attenuatus, L. macrosoma and $P$. maximus were reported only from Bulgaria. Here we present the current situation in
Bulgaria and Slovenia concerning the occurrence and distribution of longidorid nematode vectors (Figs $1-4$ ) and their associated nepoviruses.

Longidorus attenuatus has been reported from vineyards and black currant in several localities only in Bulgaria (Choleva-Abadjieva, 1975; Katalan-Gateva et al., 1982; Choleva \& Budurova, 1983).

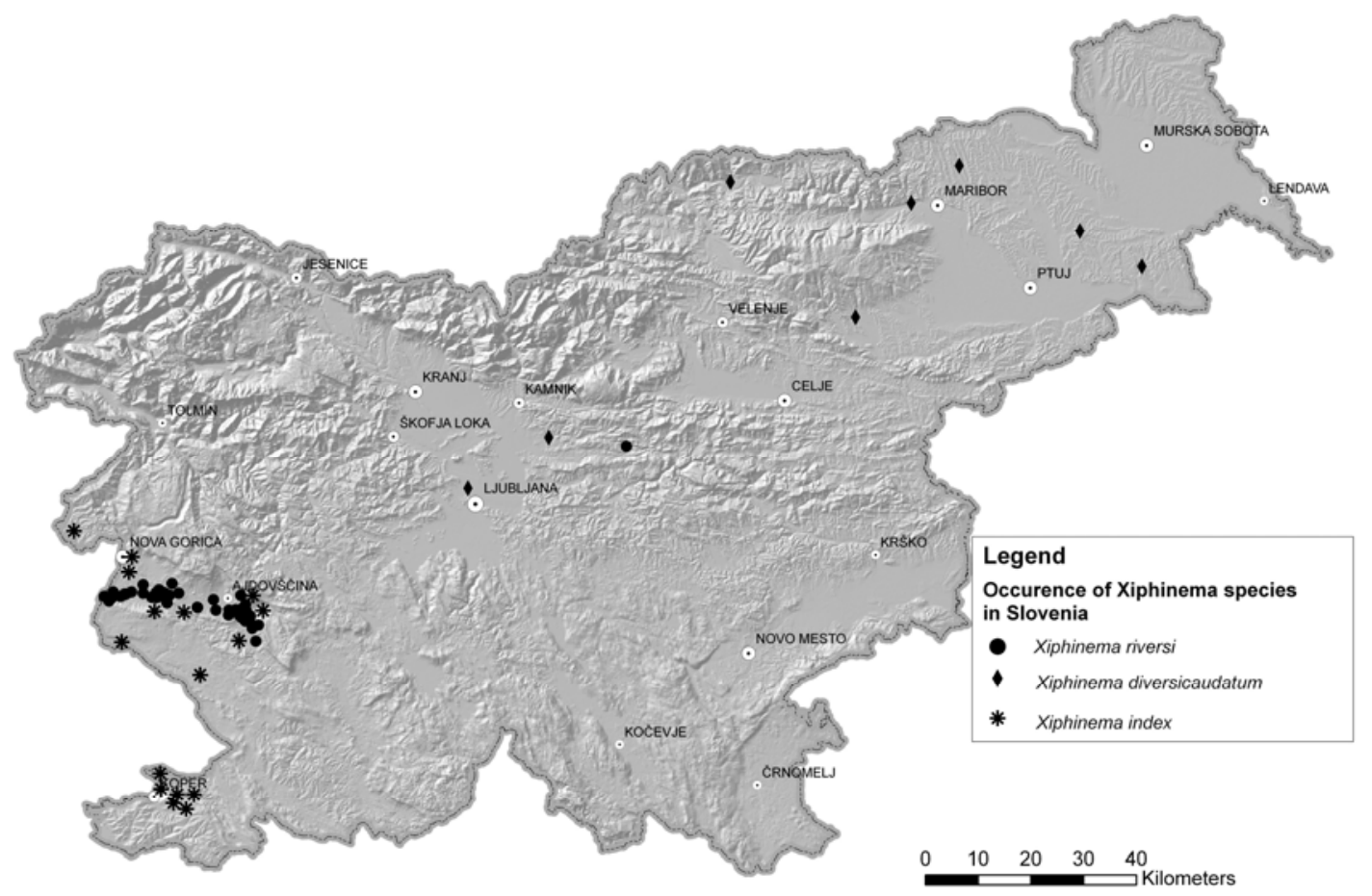



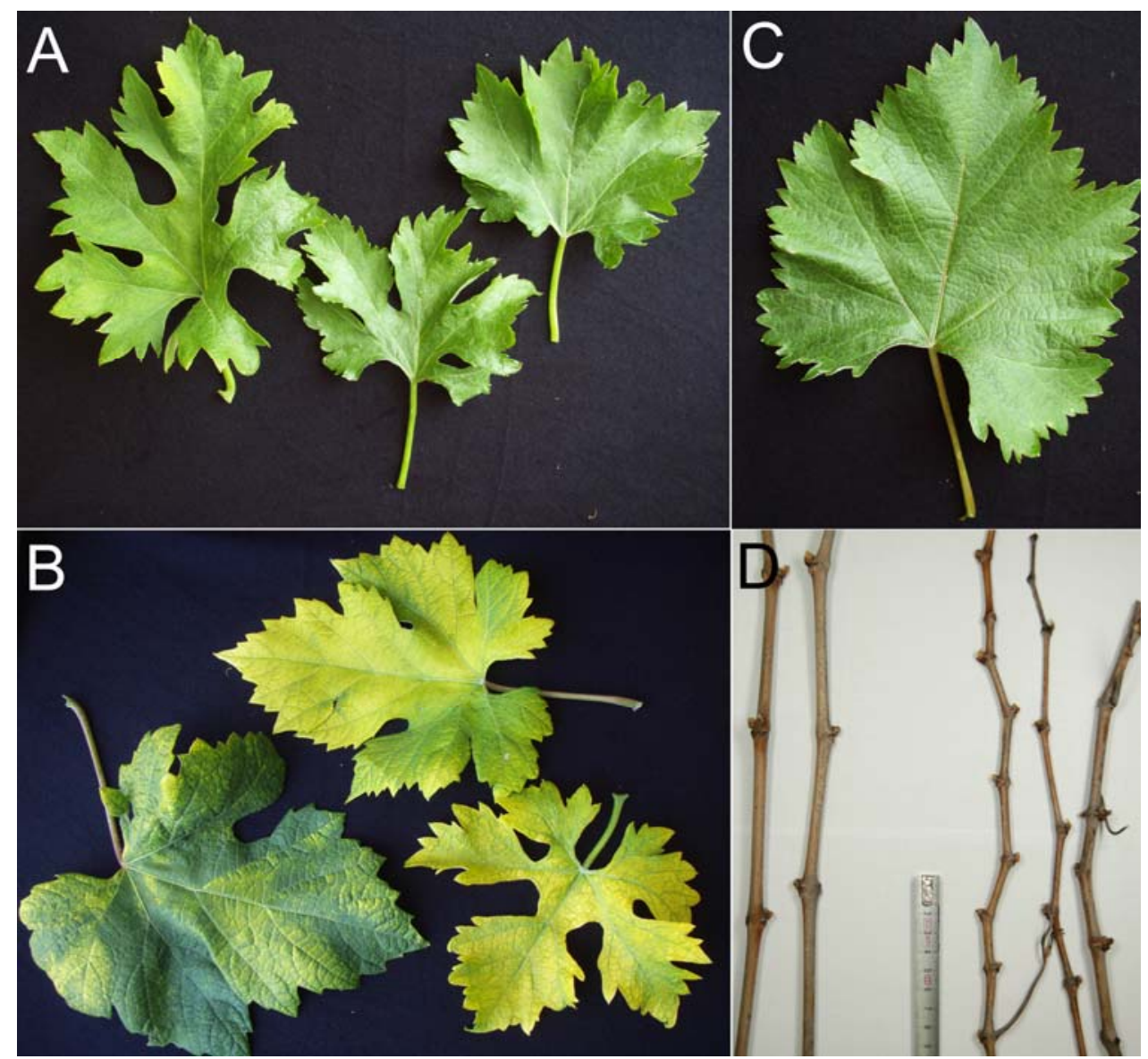

Fig. 5. GFLV infected grapevine cv. "Refošk": A - fanleaf symptoms on infected leaves, B - different patterns of discolorations on GFLV infected vine, $\mathrm{C}$ - healthy vine, D - modification of grapevine "internodium" length, left: healthy vine, right: GFLV infected vine

Longidorus macrosoma - was associated with raspberry in one locality in Bulgaria (Choleva et al., 1992).

Paralongidorus maximus - was found in only one vineyard in Galata (Lamberti et al., 1983).

Xiphinema rivesi - was recovered from several locations in the western part of Slovenia, close to the Italian-Slovenian border (Urek et al., 2003b,Urek et al., 2005) and subsequently was proven as a vector of tobacco ring-spot virus (TRSV) and tomato ring-spot virus (ToRSV) (Širca et al., 2007b).

Longidorus elongatus - is comparatively rare in Bulgaria, reported from vineyards and strawberry fields (CholevaAbadjieva, 1975; Choleva et al., 1992). In Slovenia it has been reported from vineyards and maize fields, but only in the western part of the country (Urek et al., 2003a).

Xiphinema diversicaudatum - is widespread in both countries in association with various cultivated plants (grapevine, forest trees seedlings, roses, raspberries) and wild vegetation (Choleva \& Budurova, 1983; Choleva et al., 1992, Lamberti et al., 1983; Peneva \& Choleva 1992; Urek et al., 2003a) and riparian vegetation in Bulgaria (Lazarova et al., 2010).

Xiphinema index - is common in vineyards and orchards in Bulgaria (Stoyanov \& Kostadinov, 1975; CholevaAbadjieva, 1975; Lamberti et al., 1983) and has frequently been found in association with Salix spp along rivers (Laz- arova et al., 2010). This species is reported from vineyards and fig only in the western part of Slovenia (Urek et al., 2003a; Urek \& Šrca, 2005).

Xiphinema italiae - occurs frequently in Bulgaria associated with different crops, especially grapevine and fruit trees (Stoyanov \& Kostadinov, 1975; Choleva-Abadjieva, 1975; Lamberti et al., 1983, Peneva \& Choleva, 1992b), also with river bank vegetation (Lazarova et al., 2010).

Longidorus juvenilis - was recorded from two sites in the north-eastern part of Slovenia in association with grapevine (Širca et al., 2007). Recently, Raspberry Bushy Dwarf Virus (RBDV) was detected from different grapevine varieties in Slovenia and also was recovered from L. juvenilis specimens soon after they were collected in the field as well as after 4 and 8 months of storage of infested soil in a refrigerator (Mavrič Pleško et al., 2009). The role of $L$. juvenilis in virus transmission, however, is not clear, yet and is still under investigation.

Several nepoviruses (Table 1) have been reported from Bulgaria (Martelli, 1993,; Kamenova et al., 2007; Yankulova et al., 2007; EPPO data). Currently, the only report of a relationship between $X$. index and Grapevine fanleaf virus in Bulgaria refers to transgenic grapes tolerance to the same virus (Tsvetkov et al., 2003). Recently, GFLV was detected in $X$. italiae specimens originating from a 
grapevine in Bulgaria, (Širca et al., 2010).

Several nepoviruses have been reported from Slovenia (Table 1, Pompe et al., 2007; EPPO data), but despite an evident relationship between GFLV and $X$. index in several vineyards, only the transmission of tobacco and tomato ring-spot nepovirus (TRSV) and (ToRSV) to bait plants by a Slovenian population of $X$. rivesi has been verified in the laboratory (Śirca et al., 2007b). However, these two viruses do not occur in Slovenia (Geric Stare et al., 2009). Nepoviruses ArMV and GFLV, and the Idaeovirus RBDV are frequently found in grapevine production areas throughout Slovenia (Geric Stare et al., 2009) and GFLV infection can be recognized by distinct symptoms (Fig 5) in grapevine varieties.

A wide range of horticultural and agricultural crops are affected by longidorid nematodes and their associated viruses but these virus and crop interactions have not yet been sufficiently studied in Slovenia and Bulgaria. Consequently, more extended research on longidorid nematodes and their associated nepoviruses is now being conducted in these two countries in order to develop and establish control strategies for reducing the detrimental impact of these pathogens on agriculture and horticulture.

\section{Acknowledgements}

The study was supported by the Bulgarian National Science Fund, project N DOO2-101/2008 and Slovenian Research Agency, project BI-BG/09-10-009.

\section{References}

Abrantes, I. M. De O., Santos, M. S. N. De A. (1997): General principles of nematode identification. In: SANTOS, M. S. N. De A., Abrantes, I. M. De O., Brown, D. J. F., LEMOS, R. M. (Eds) An introduction to virus vector nematodes and their associated viruses. Instituto do Ambiente $\mathrm{e}$ Vida, Coimbra, Portugal, pp. 113 - 127

Alphey, T. J. V., TAYloR, C. E. (1986): European atlas of the Longidoridae and Trichodoridae. Scottish Crop Research Institute, Dundee, $123 \mathrm{pp}$.

ARIAS, M., BRAVO, M. A. (1997): Identification of genera and species in subfamily Longidorinae. In: SANTOS, M. S. N. De A., Abrantes, I. M. De O., Brown, D. J. F., Lemos R. M. (Eds) An introduction to virus vector nematodes and their associated viruses. Instituto do Ambiente e Vida, Coimbra, Portugal, pp. $128-176$

BROWN, D. J. F., BOAG, B. (1997): Sampling for virus vector nematodes. In: SAntos, M. S. N. De A., Abrantes, I. M. DE O., BRown, D. J. F., LEMOS R. M. (Eds) An introduction to virus vector nematodes and their associated viruses. Instituto do Ambiente e Vida, Coimbra, Portugal, pp. 69 - 96

BROWN, D. J. F., HALBRENDT, J. M. (1997): Identification of Xiphinema species (Nematoda: Dorylaimoidea). In: Santos, M. S. N. De A., ABrantes, I. M. De O., Brown, D. J. F., LEMOS, R. M. (Eds) An introduction to virus vector nematodes and their associated viruses. Instituto do Ambiente e Vida, Coimbra, Portugal, pp. 177 - 223
Brown, D. J. F. Weischer, B. (1998): Specifity, exclusivity and complementarity in the transmission of plant viruses by plant parasitic nematodes: an annotated terminology. Fundam. Appl. Nematol., 21: 1 - 11

CADMAN, C. H. (1963): Biology of soil-borne viruses. Annu. Rev. Phytopathol., 1: $143-142$

Catalano, L., Savino, V., Lamberti, F. (1992): Presence of grapevine fanleaf nepovirus in populations of longidorid nematodes and their vectoring capacity. Nematol. Mediterr., 20: $67-70$

Choleva-AbadjIeVA, B. (1975): [Study on the species composition and distribution of nematodes of the family Longidoridae (Nematoda, Dorylaimoidea) on the vine in Bulgaria.] Acta Zool. Bulg., 3: 19 - 30

Choleva, B., Budurova, L. (1983): [Parasitic nematode species on black current (Ribes nigrum var europaeum L.).] Acta Zool. Bulg., 21: 67 - 77

Choleva, B., Peykova, Y., Nedelchev, S. (1992): Study of distribution of nematode virus vectors (Fam. Longidoridae) of raspberry crops in Bulgaria. Khelminthologiya, 32: $5-10$

Cohn, E., Tanne, E., Nitzany, F. E. (1970): Xiphinema italiae, a new vector of grapevine fanleaf virus. Phytopathology, 60: $181-182$

CoOmans, A., Huys, R., Heyns, J., LuC, M. (2001): Character analysis, phylogeny and biogeography of the genus Xiphinema Cobb, 1913 (Nematoda: Longidoridae). Annales Sciences Zoologiques, Muse'e Royal de l'Afrique Centrale, Tervuren, 287: 1-239

De LuCA, F., ReYes, A., Grunder, J., KunZ, P., Agostinelli, A., De Giorgi, C., LAmberti, F. (2004): Characterization and sequence variation in the rDNA region of six nematode species of the genus Longidorus (Nematoda). J. Nematol., 36: 147 - 152

Digiaro, M., Elbeaino, T., Martelli, G. P. (2007): Development of degenerate and species-specific primers for the differential and simultaneous RT-PCR detection of grapevine-infecting nepoviruses of subgroups A, B and C. J. Virol. Methods, 141 (1): $34-40$

DuArTe, I. M. N., Brown, D. J. F. (1997): Sampling, detection and identification of nematode transmitted viruses. In: Santos, M. S. N. De A., Abrantes, I. M. De O., Brown, D. J. F., LEMOS, R. M. (Eds) An introduction to virus vector nematodes and their associated viruses. Instituto do Ambiente e Vida, Coimbra, Portugal, pp. 313 - 355 Geric Stare, B., KNAPIČ, M., MaVrič, I., Modic, Š., Munda, A., ŠIrCA, S., ŠKerlavaJ, V., UreK, G., URBANČIČ, Z. M., VIRŠČEK MARN, M., ZIDARIČ, I., ŽERJAV, M. (2009): [Technical report of expert work on plant protection for 2009]. Ljubljana, Kmetijski inštitut Slovenije, 2009, pp. 122

HARRISON, B. D. (1961): Soil borne viruses - tobacco rattle virus. Annual report of Rothamsted Experimental Station for 1961, England, $118 \mathrm{pp}$.

HARRISON, B. D. (1964): Specific nematode vectors for serologically distinctive forms of raspberry ringspot and tomato black ring viruses. Virology, 22: $544-550$

He, Y., Subbotin, S. A., Rubtsova, T. V., Lamberti, F., 
Brown, D. J. F., MoEns, M. (2005): A molecular phylogenetic approach to Longidoridae. Nematology, 7: $111-124$

Hewitt, W. B., Raski, D. J., Goheen, A. C. (1958): Nematode vector of soil borne virus of grapevines. Phytopathology, 48: 586 - 595

HoOPER, D. J. (1986): Extraction of free-living stages from soil. In: Laboratory methods for work with plant and soil nematodes (Ed. by Southey, J.F.), pp. 5-30. Reference Book, Ministry of Agriculture, Fisheries and Food No. 402. Her Majesty's Stationery Office, London, UK.

Hubschen, J., Kling, L., IPACH, U., Zinkernagel, V., Brown, D. J. F., NeILson, R. (2004): Development and validation of species-specific primers that provide a molecular diagnostic for virus-vector longidorid nematodes and related species in German viticulture. Eur. J. Plant Pathol., 110: 883 - 891

Hunt, D. (1993): Aphelenchida, Longidoridae and Trichodoridae: their systematics and bionomics. CAB International, Wallingford, $352 \mathrm{pp}$.

Kamenova, I., TsvetKov, I., Atanasov, A. (2007): Virus testing of certified grapevine planting material in Bulgaria. Biotechnology and Biotechnological Equipment, 21: 66 68

Katalan-Gateva, S., Budurova, L., Choleva, B. (1982): [Phytonematode fauna of the grapevine (Vitis vinifera L) from district of Blagoevgrad.] Annuaire de L'Universite de Sofia “Kliment Ohridski”, Livre 1- Zoologie, 70: $55-61$

Lamberti, F., Choleva, B., Agostinelli, A. (1983): Longidoridae from Bulgaria (Nematoda: Dorylaimida) with descriptions of three new species of Longidorus and two new species of Xiphinema. Nemat Mediterr., 11: 49 - 72

Lamberti, F., Molinari, S., Moens, M., Brown, D. J. F. (2000): The Xiphinema americanum group. I. Putative species, their geographical occurrence and distribution. Russian Journal of Nematology, 8: $65-84$

Lazarova S., De Luca F., Peneva, V. 2008. On two closely related species of the Xiphinema americanumgroup: $X$. simile Lamberti, Choleva et Agostinelli, 1983 and $X$. parasimile Barsi et Lamberti, 2004 (Longidoridae), with a description of the male of $X$. parasimile. ZooKeys 3 , $29-50$.

Lazarova, S., Elshishka, M., Groza, M., Peneva, V. (2010): Nematodes of Longidoridae and Trichodoridae from riparian habitats in Bulgaria. Proceedings of the $30^{\text {th }}$ ESN Symposium, Vienna, 19 - 23 September 2010, p. 127 Loof, P. A. A., CHEN, Q. (1999): A revised polytomous key for the identification of species of the genus Longidorus Micoletzky, 1922. Supplement 1. (Nematoda: Dorylaimida). Nematology, 1: 55 - 59

MacFarlane, S. A., NeIlson, R., Brown, D. J. F. (2002): Nematodes. Advances in Botanical Research, 36: $169-$ 198

MARTElLI, G. P. (1993): Graft-transmissible diseases of grapevines. Handbook for detection and diagnosis. FAO, Rome, Italy, 263 pp.

MincheVA, Y., Lazarova, S., Peneva, V. (2008): Xiphinema pirinense n. sp. (Dorylaimida: Longidoridae), a new species with a digitate tail from Bulgaria. Syst. Parasitol., 70: 215 - 222

Peneva, V., Choleva., B. (1992): Nematodes of the family Longidoridae from forest nurseries in Bulgaria. II. Genus Xiphinema Cobb, 1913. Khelminthologyia, 32: 47 66

Peneva, V., Lazarova, S., Groza, M., Brown, D. J. F. (2005): Diversity of fam. Longidoridae (Nematoda) in Bulgaria. Abstracts of the Seventh National Conference of Prasitology, 22 - 25 September 2005, p. 99

MAVRiČ PlešKo, I., MARN, M. V., ŠIRCA, S., UREK, G. (2009): Biological, serological and molecular characterisation of Raspberry bushy dwarf virus from grapevine and its detection in the nematode Longidorus juvenilis. Eur. J. Plant Pathol., 123 (3): 261 - 26

Ploeg, A. T., Brown, D. J. F. (1997): Extraction of virus vector nematodes. In: SANTOS, M. S. N. DE A., ABRANTES, I. M. De O., Brown, D. J. F., Lemos R. M. (Eds) An introduction to virus vector nematodes and their associated viruses. Instituto do Ambiente e Vida, Coimbra, Portugal, pp. $97-112$

Pompe NovaK, M., Gutierrez-Aguirre, I., VoJvoda, J., Blas, M., TOMAŽıČ, I., VIGNe, E., FuchS, M., RAVNIKAR, M., PETROVIČ, N. (2007): Genetic variability within RNA2 of grapevine fanleaf virus. Eur. J. Plant Pathol., 117: 307 $-312$

SEINHORST, J. M. (1959): A rapid method for the transfer of nematodes from fixative to anhydrous glycerin. Nematologica, 4: 67-69

ŠIRCA, S., UREK, G. (2004): The occurrence of Xiphinema species in Slovenia. In: European Society of Nematologists XXVII International Symposium: Rome, 14 - 18 June 2004: Programme and Abstracts, p 62

ŠIrCA, S., Geric StARE, B. MAVRIČ PlešKo, I., MARN, M. V., UREK, G. (2007a): First record of Longidorus juvenilis and L. leptocephalus (Nematoda: Dorylaimida) in Slovenia and their morphometrical and ribosomal DNA sequence analysis. Russ. J. Nematol., 15 (1): $1-8$

ŠIrCA, S., Stare, B. G., MAVRIČ PleŠKO, I., MARN, M. V., UREK, G., JAVORNIK, B. (2007b): Xiphinema rivesi from Slovenia transmit Tobacco ringspot virus and Tomato ringspot virus to Cucumber Bait Plants. Plant Dis., 91 (6): 770

ŠIrCA, S., UREK, G. (2009): Morphological and molecular characterization of six Longidorus species (Nematoda: Longidoridae) from Slovenia. Russ. J. Nematol., 17 (2): 95 $-105$

ŠIrCA, S., ElShishKa, M., UREK, G., LAZAROVA, S., Mavrič PlešKo, I., Marn, M. V., Peneva, V. (2010): Detection of Grapevine fanleaf virus (GFLV) in Xiphinema italiae Meyl, 1953 (Longidoridae) from Bulgaria. Proceedings of the 30th ESN Symposium, Vienna, $19-23$ September 2010, 113

StOyanov, D., Kostadinov, A. (1975): [Distribution of some parasitic nematodes of family Longidoridae in vineyrds in Bulgaria.] Lozarstvo $i$ Vinarstvo, 24: 16 - 20 TAYLOR, C. E., BROWN, D. J. F. (1997): Nematode vectors of plant viruses. CAB International, Wallingford, UK, 286 pp. 
Trudgill, D. L., Brown, D. J. F., Mcnamara, D. G. (1983): Methods and criteria for assessing the transmission of plant viruses by longidorid nematodes. Rev. Nematol., 6: $133-141$

Tsvetkov, I., Choleva, B., Yankulova, M., Colova, V., Atanasov, A. (2003): Evaluation of transgenic grapes tolerance toward grapevine fanleaf virus. Proceedings of the $14^{\text {th }}$ ICVG Conference, $231-232$

UreK, G., ŠIrCA, S., KARssen, G. (2003a): A review of plant-parasitic nematodes in Slovenia. Nematology, 5: 391 $-403$

Urek, G., ŠIrcA, S., KoX, L., Karssen, G. (2003b): First report of the dagger nematode Xiphinema rivesi, a member of the $X$. americanum group, from Slovenia. Plant Dis., 87(1): 100

UREK, G., ŠIRCA, S. (2005): Longidoridae species from Slovenian vineyard soils. Lectures and papers presented at the 7th Slovenian Conference on Plant Protection, Zreče,
Slovenia, 8 - 10 March 2005, DRSV 2005, 356 - 359

UREK, G., ŠIrCA, S., KARSSEN, G. (2005): Morphometrics of Xiphinema rivesi Dalmasso, 1969 (Nematoda: Dorylaimida) from Slovenia. Russ. J. Nematol., 13: 13 - 17

WANG, S., GERDERICH, R. C. (1998): Immunofluorescent localization of tobacco ringspot nepovirus in the vector nematode Xiphinema americanum. Phytopathology, 88: $885-889$

Yankulova, M., TsvetKov, I., KAmEnOV, I., Kondakova, V., VulcheV, V. (2007): Grapevine virus disease in Bulgaria. Lozarstvo $i$ Vinarstvo, 56(1): $19-24$ YE, W. M., ROBBINS, R. T. (2004): Cluster analysis of Longidorus species (Nematoda: Longidoridae), a new approach in species identification. J. Nematol., 36: $207-218$ Ye, W. M., Szalanski, A. L., RobBins, R. T. (2004): Phylogenetic relationships and genetic variation in Longidorus and Xiphinema species using ITS1 sequence of ribosomal DNA. J. Nematol., 36: 14 - 19 